\title{
GROUT ANALYSIS FOR EC AND CC CALORIMETERS
}

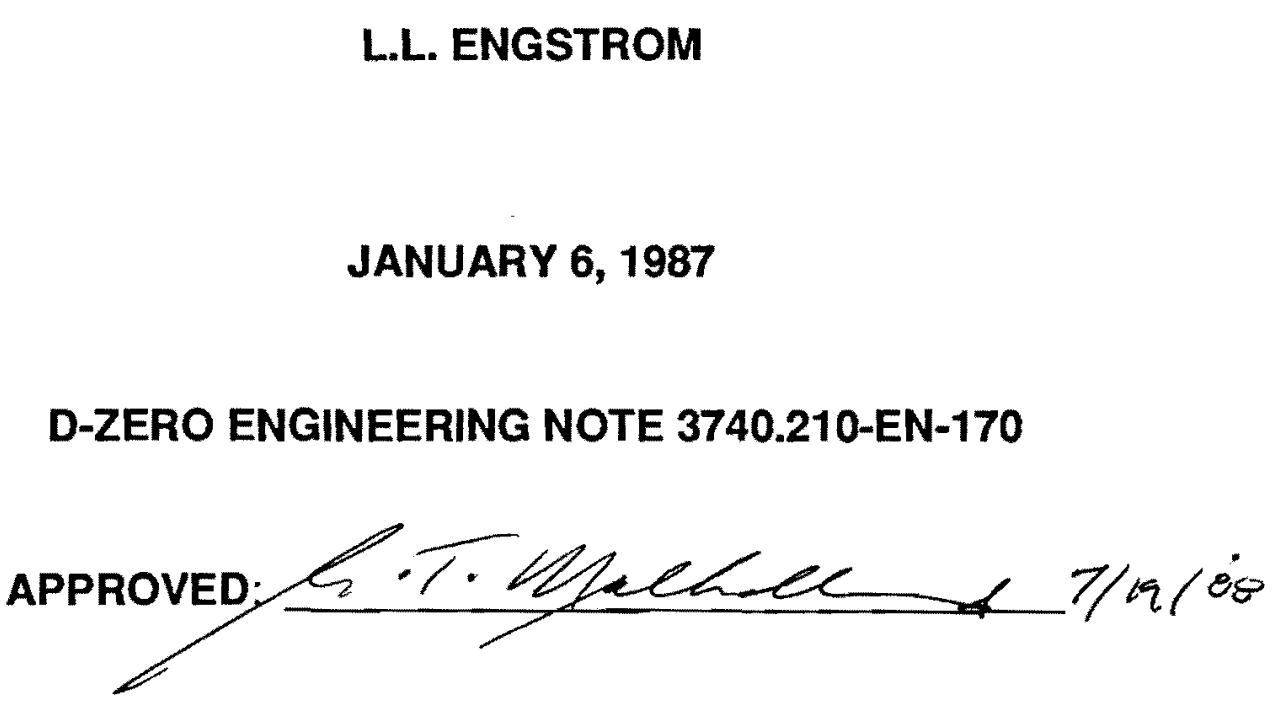

L.L. ENGSTROM

JANUARY 6, 1987 
Grout Analysis for EC and CC Calorimeters

L. L. Engstrom

\section{Introduction}

The EC and CC calorimeters roll on Two parallel hardened steel ways which reside on the top of the D0 platform's center beam. The ways will be grouted to the center beam once their correct elevation has been established. The purpose of this report is to evaluate and compare three different epoxy grouts and their properties for this application.

\section{Previous Experience}

Herman Streede grouted the six ways that the platform rolls on using an epoxy grout called Unisorb. The elevation of the ways was maintained with two sets of leveling screws. One set was used to close the gap between the way's lower surface and the concrete floor. The other set increased the gap. The gap thickness was approximately 10 mils to .2" along the length of the way. Once the required elevation was achieved, grout was forced into the gap under nitrogen pressure.

\section{Calorimeter Ways}

The engineering data for three epoxy grouts is given on page 2. Grout literature for the three materials is given in Appendix B. Grout calculations are contained in Appendix A. A list of pertinent phone numbers and addresses is given on page 3 .

Steve Trout, a grout contractor, was contacted for a budget estimate of the job. As of this writing, he has not returned the information he promised. 
GROUT PROPERTIES

$\begin{array}{llccc} & \begin{array}{l}\text { ESCOWELD } \\ \text { 7570 CHOCK }\end{array} & \begin{array}{l}\text { UNISORB } \\ \text { V-100 }\end{array} & \begin{array}{c}\text { FIVE STAR } \\ \text { EPOXY }\end{array} \\ \text { VISCOSITY (CPS) } & 45 & 15 / 30 & 45 \\ \text { SHRINKAGE (IN/IN) } & .00017 & 6000 & \text { ND } \\ \text { EXP. COEFF. (/F) } & 8.46 \mathrm{E}-6 & .0013 & 0.00 \% \\ \text { COMP. STR. (KSI) } & 22.6 & 2 \mathrm{E}-5 & 27 \mathrm{E}-6 \\ \text { COMP. MODULUS (KSI) } & 632 & 16.8 & 12.0 \\ \text { TENSILE STR. (KSI) } & 9.9 & 1100 & \text { ND } \\ \text { FLEXURAL STR. (KSI) } & \mathrm{ND} & 4.26 & 2.0 \\ \text { FLEX. MODULUS (KSI) } & \mathrm{ND} & 6.8 & 4.0 \\ \text { PEAK EXOTHERM(F) } & 175 & 1260 & 1500 \\ \text { COST (\$) } & 1851.40 & \mathrm{ND} & 110\end{array}$

\section{NOTES:}

ESCOWELD 7570 DOES NOT CONTAIN AN AGGREGATE. FIVE STAR EPOXY CONTAINS AN AGGREGATE. ND SIGNIFIES NO DATA AVAILABLE. 
GROUTS:

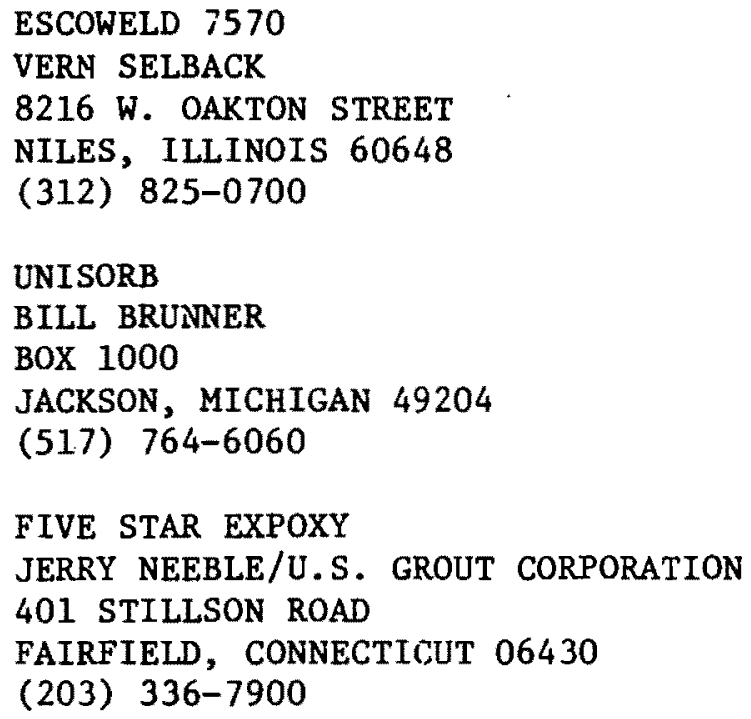

DON HEGEBARTH

9 S. 115 CHANDELLE DRIVE NAPERVILLE, ILLINOIS 60565

(312) 416-9115

GROUT CONTRACTOR: (REFERRED BY DON HEGEBARTH)

STEVE TROUT

(312) $892-0830$ 


\section{APPENDIX A GROUT CALCULATIONS}




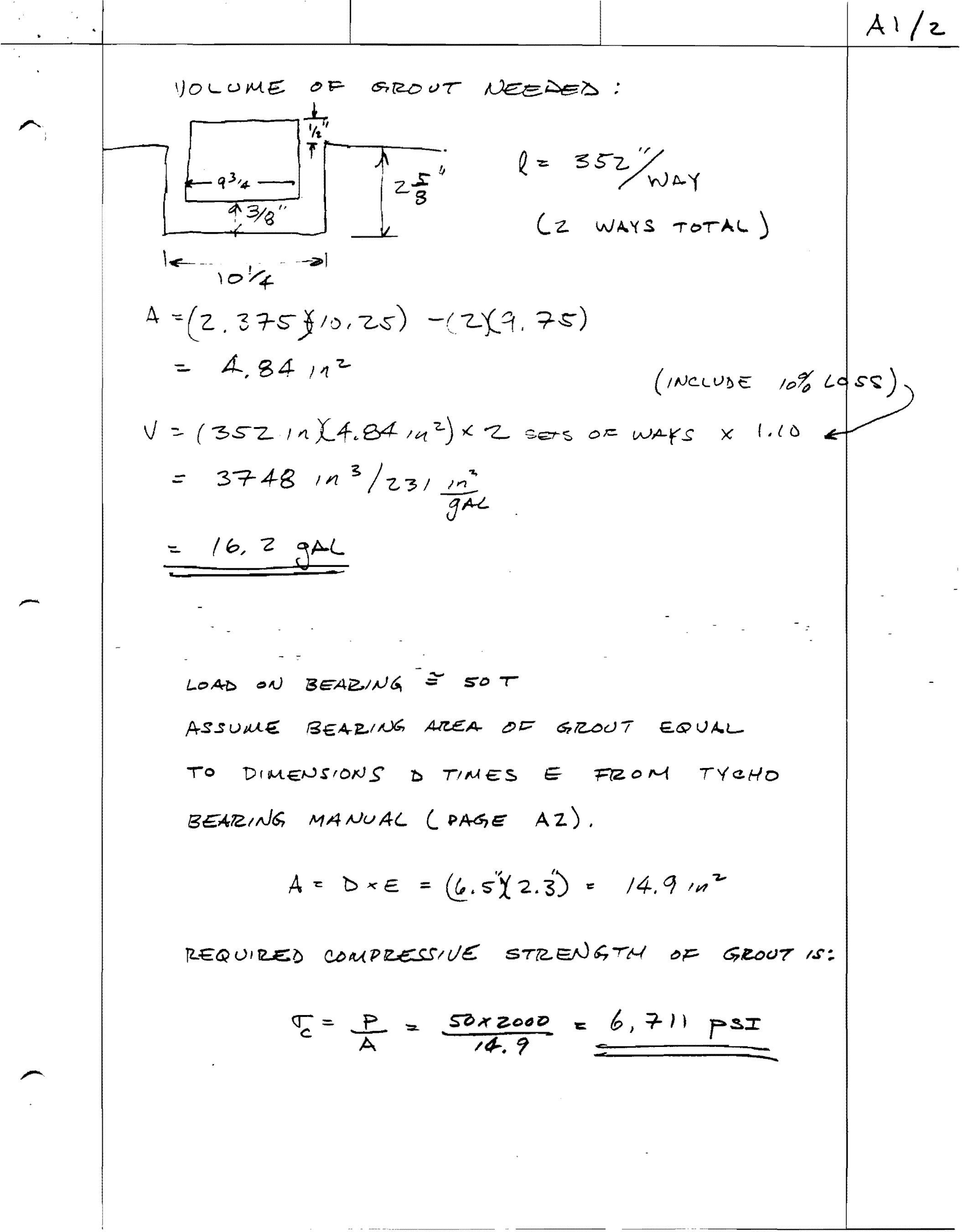




\section{Dimensions, Specifications}
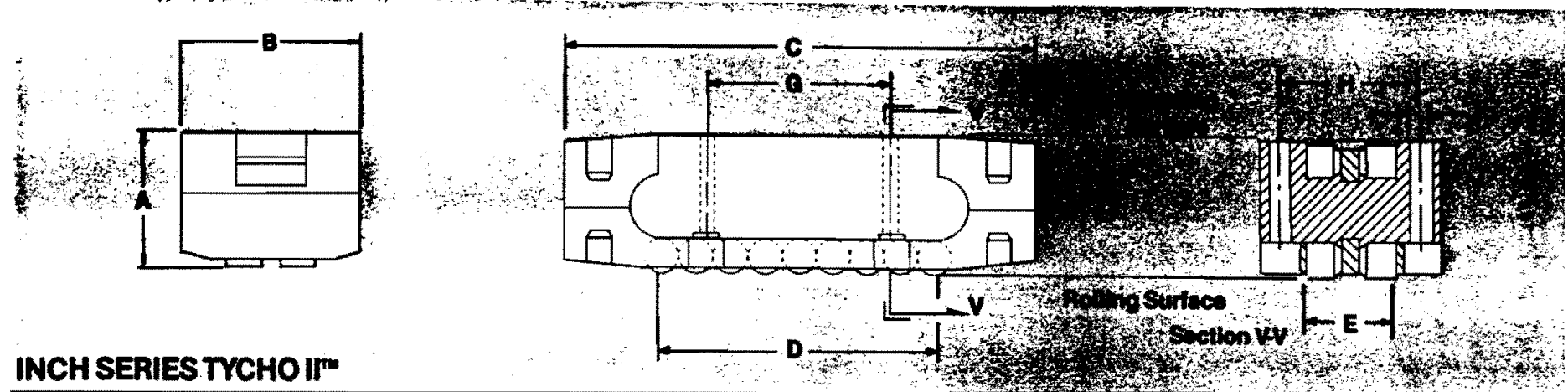

INCH SERIES TYCHO II"

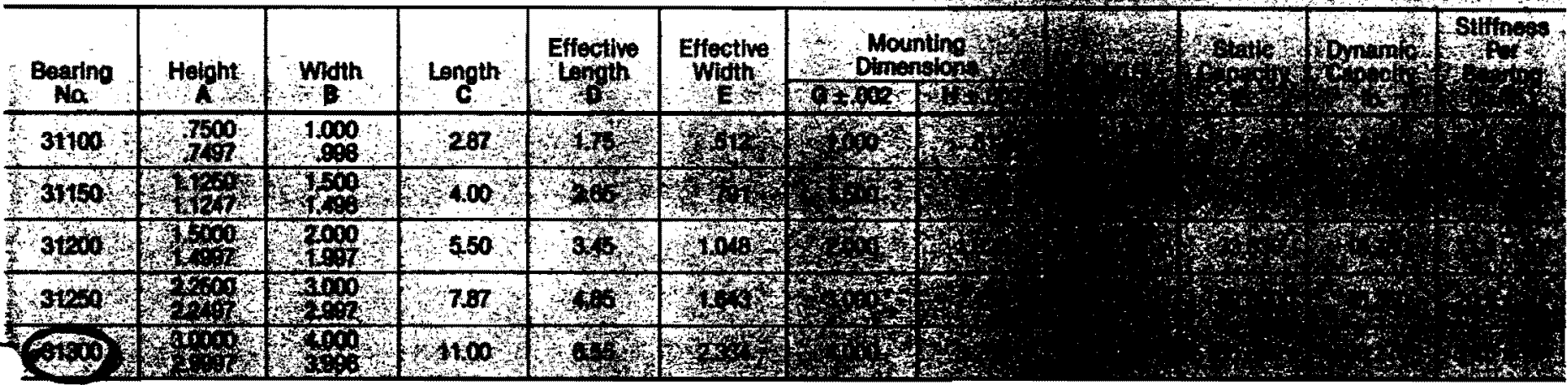

METRIC SERIES TYCHO $\|^{\mathrm{m}}$

\begin{tabular}{|c|c|c|c|c|c|c|}
\hline Bearing & Heigh: & Wath: & longth & $\begin{array}{l}\text { Eftectwo } \\
\text { tength }\end{array}$ & 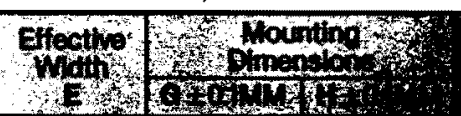 & W \\
\hline 32100 & 13 & 27 & 75 & W5 & 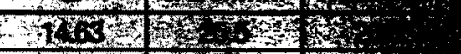 & 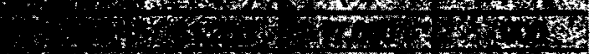 \\
\hline 32150 & 29 & $\$ 40$ & 108 & $6 x^{3}$ & $2+84=137$ & S. \\
\hline 3020 & 38 & 52 & 139 & 876 & 3048251 & 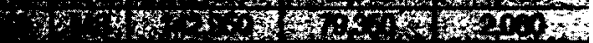 \\
\hline
\end{tabular}

$-$

TYCHO II"*
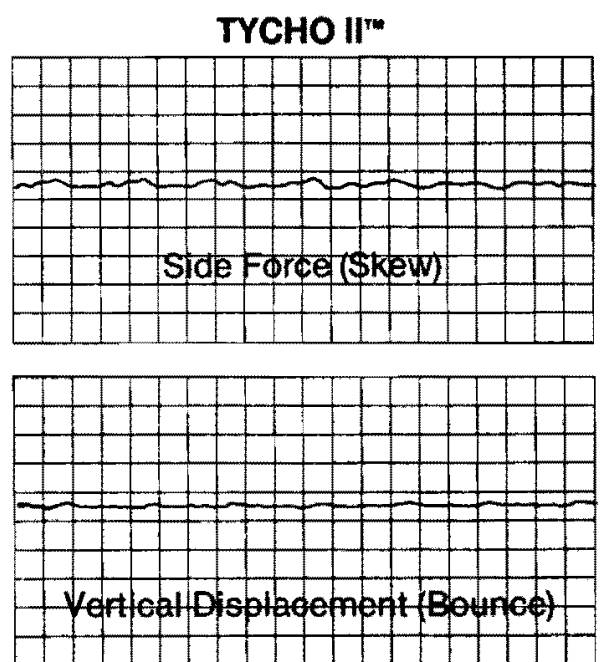

"(On Skew Section, each line represents 25 pounds; on Bounce Section, each line represents .0001 inches.)

Best Performing Competitor
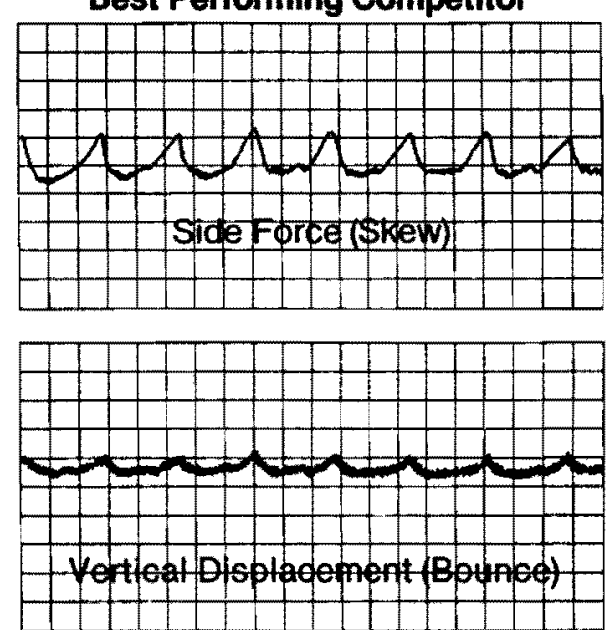

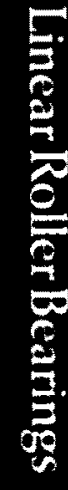

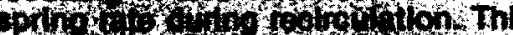

bath of

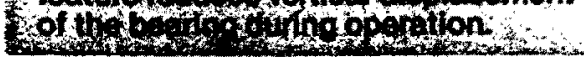

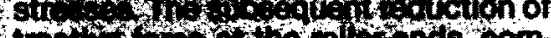

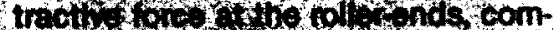

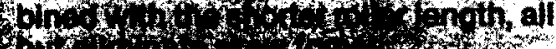

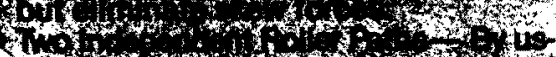

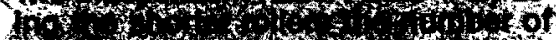

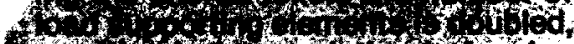

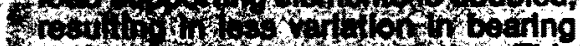




\section{APPENDIX B GROUT LITERATURE}




\section{ESCOWELD 7570 Epoxy Chock}

ESCOWELD 7570 Epoxy Chock is a versatile two-component epoxy chocking compound that has the strength and relative chemical inertness of epoxy resins plus the toughness of polyamine-type curing agents. The two liquid components are mixed in their own containers prior to application.

ESCOWELD 7570 Epoxy Chock is designed to meet the stringent chocking requirements of industrial applications. Its resistance to chemical and physical degradation is excellent. The material flows freely into the prepared chock area forming a perfectlyfitted solid chock. Its high compressive strength and creep resistant formulation will maintain equipment alignment.

Because of the ease of application, there is a considerable reduction in time and cost of installation when compared to machining of foundations and the hand-fitting of chocks. Twentyfour hours after pouring, the material normally reaches its design strength (see "Curing" information).

\section{ESCOWELD 7570 Epoxy Chock is used for:}

- Chocking original installation of heavy precision equipment such as compressors, pumps and milling machines, and other machinery.

- Repairing damaged chocking installations of precision equipment.

- Rechocking heavy equipment such as compressors, pumps, engines, and other machinery.

When prepared and installed as recommended, ESCOWELD 7570 Epoxy Chock offers the following advantages:

- Long life service.

- High resistance to chemical and physical degradation.

- Exceptional dimensional stability.

- Reduced downt ime.

- Rapid and economical chock replacement.

- Low creep compliance. 
ESCOWELD 7570 Epoxy Chock Typical Physical Properties

Compressive Strength, $70^{\circ} \mathrm{F}$, psi

(ASTI D695)

Compressive Modulus of El asticity, $70^{\circ} \mathrm{F}$, psi (ASTI D695)

Tensile Strength, $70^{\circ} \mathrm{F}$, psi

(ASTI D638)

1200 Impact Resistance, $70^{\circ} \mathrm{F}, \mathrm{ft} 1 \mathrm{~b} /$ in

(ASTI D256)

Shrinkage on Cure, in Lin

TASTM-02566)

Coefficient of Thermal Expansion, in/ in ${ }^{\circ} \mathrm{F}$ (ASTI D696).

Density, cured, Ibs/cu ft

Approximate Working Life, $70^{\circ} \mathrm{F}$, wins

Approximate Cure Time, $70^{\circ} \mathrm{F}$, hours

She if Life, years
22,600

$6.32 \times 10^{5}$

9,900

0.417

0.00017

$8.46 \times 10^{-6}$

90

45

24

2 


\section{ESCONELD 7570 EPOXY CHOCK}

\section{PART A RESIN}

\section{WARNING! \\ CAUSES SKIN IRRITATION ON PROLONGED CONTACT COMBUSTIBLE \\ MAY CAUSE EYE IRRITATION VAPORS IRRITANT}

PRECAUTIONS - Keep away from heat, sparks and open flames. Avoid eye contact. Avoid contact with skin and clothing. Avoid breathing mists or vapors. Use with ventilation equal to unobstructed outdoors in moderate breeze. Keep container closed. Wash thoroughly after handing.

FIRST AID - Wash skin with soap and water. Flush eyes with plenty of water unt il irritation subsides. Remove to fresh air. If not breathing, apply artificial respiration and CALL A PHYSICIAN.

\section{PART B CONYERTER}

\section{DANGER! \\ CAUSES SKIN AND EYE BURNS \\ PROLONGED OR REPEATED EXPOSURE MAY \\ LEAD TO SKIN SENSITIZATION}

PRECAUTIONS - Do not get in eyes or on clothing. Wear suitable protective clothing and chemical safety goggles. Avoid breathing mists or vapors. Use with ventilation equal to unobstructed outdoors in moderate breeze.

FIRST AID - Immediately flush eyes and skin with plenty of water for at least 15 minutes while contaminated clothing and shoes are removed. CALL A

PHYSICIAN. Launder clothing before reuse. Discard grossly cont aminated shoes.

PART A AMD PART B

FIRE FIGHTING - Use water spray to cool fire-exposed surfaces and protect personnel. Extinguish, preferentially with dry chemical, foam, waterspray or waterfog.

SPILL CONTROL - Keep public away. Eliminate sources of ignition. Shut off source, if possible to do so safely. Prevent liquid from entering sewers or watercourses. Advise authorities if material has entered a watercourse or sewer or has contaminated soil or vegetation. Contain spilled liquid with sand or earth. Recover by pumping or with suitable absorbent. Consult an expert on disposal of recovered material and ensure conformity with local disposal regulations. 
A seven and one-half pound (7.5 lb.) unit of ESCONELD 7570 Epoxy Chock contains 143 cubic inches of material when mixed. Four units are packaged per case. Since scraping of the sides of the container while pouring is not recommended, use 125 cubic inches when estimating chocking requirements.

IMPORTANT STORAGE AND MIXING INSTRUCTIONS

- ESCOMELD 7570 Epoxy Chock should be stored upside down, at room temperature $\left(70^{\circ}-80^{\circ} \mathrm{F}\right)$ for 24 hours prior to use. This will insure proper viscosity for mixing and pouring.

- Read all instructions before mixing. Mix with a power stirrer at approximately $200 \mathrm{rpm}$ (maximum $400 \mathrm{rpm}$ ) using a Jiffy type blade. Mixing should be completed wihin two to three minutes after the converter is added.

- CAUTION - Do not over mix or whip air into the material. Do not mix until all molds or dams are in place.

POURING

Material should be poured without delay after mixing is complete. Care must be taken not to trap air while pouring. For best results, each chock should be poured from one side when possible. Damned area is to be filled to one-half inch over the highest point of each chock to provide a reservoir to ensure filling of voids. Do not scrape unmixed material from sides and bottom of container into the chock. Any material which shows signs of incomplete mixing should either be re-mixed or discarded.

CURING

ESCONELD 7570 Epoxy Chock cures at room temperat-ure. Heat sources are unnecessary at temperatures above $55^{\circ} \mathrm{F}$. Poured material will gel in 30 to 60 minutes and cure hard in 12 to 48 hours depending on ambient temperature.

\begin{tabular}{ll} 
Temperature & Cure Time \\
\hline $55^{\circ}-65^{\circ} \mathrm{F}$. & 48 hours \\
$66^{\circ}-70^{\circ} \mathrm{F}$ & 24 hours \\
Above $70^{\circ} \mathrm{F}$. & $12-18$ hours
\end{tabular}

Since the use of this material is specific to each application, consult your Exxon Chemical Technical Sales Representative for appropriate recommendations. A three-part Specification and Design Guideline is available to assist you in obtaining the maximum strengths and other excellent physical properties of ESCONELD 7570 Epoxy Chock. 


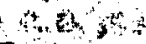

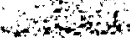

BASE PREPARATION - For best economy and optimum installation, leave approximately $1 / 2$. of space between machine base and foundation. Be careful to remove loose or weak concrete from foundation surfaces and to clean machine base if adhesion is desired. Concrete foundation must be firm, although Unisorb V-100 Grout will flow into cracks as small as .002" and strengthen entire structure. If foundation is metal, sand to roughen surfaces and wipe solvent for best adhesion.

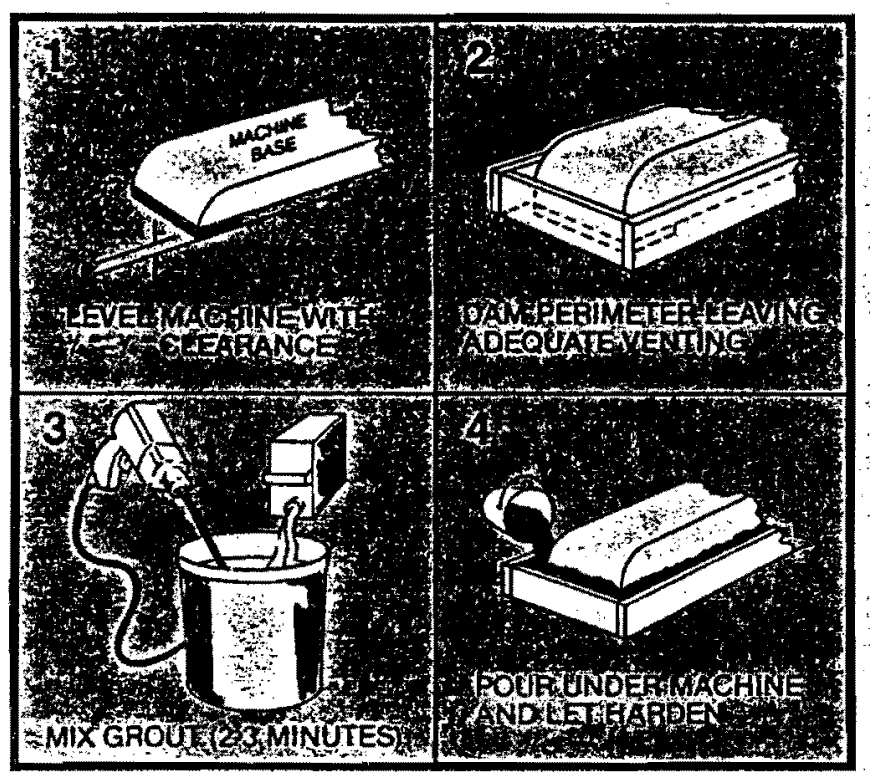

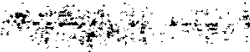

Dam the grout area if it is not already recessed. Use $2 \times 4$ 's to enable resin to build at least a $2^{\prime \prime}$ head. Apply one to two polished coatings of a good paste wax to the side of a $2 \times 4$ that contacts the resin. Then, liberally apply a $1 / 64^{\prime \prime}$ to $1 / 32^{\prime \prime}$ unpolished wax coating on these sides. Place caulking compound or ribbon putty on the floor side and abutting ends of $2 \times 4$ 's. Be certain that joints of dam are well sealed. Anchor forms in place.

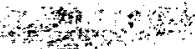

RESIN PREPARATION - Store material between $70^{\circ} \mathrm{F}$. and $80^{\circ} \mathrm{F}$. Do not mix until ready to pour.

Pot life at $77^{\circ} \mathrm{F}$. is 15 minutes. This can be extended slightly, if necessary, by swirling mixture to delay heat buildup in center of mass.

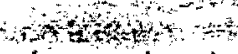

When ready to pour, premix resin portion (gray colored liquid) for one or two minutes with stirrer in power drill to assure uniform filler distribution. Note: Stirrer blade must be able to touch bottom of pail. Do not use stirrer with hindrance under blade.

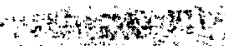

While stirring thoroughly mixed resin, pour in hardener. To prevent splashing, pour in a steady stream about $6^{\prime \prime}$ high. Mixing time should be about two minutes. Run stirrer around pail perimeter, up and down, and hold at a slight angie until y:u note uniform color and an absence of streaks.

POURING MIXED RESIN - AJways pour from one spot to prevent air inclusions under the machine. When resin has penetrated to other side of base, move pour spot along same side of base to where resin has stopped. Pour until resin is at least $1 / 2^{\prime \prime}$ up side of base. When resin has filled to bottom of opposite and adjacent sides of base, it is acceptable to fill in sides by pouring around base perimeter.

REMOVING FORMS - If temperature has been maintained at $77^{\circ} \mathrm{F}$. during entire pouring procedure, it is possible to remove forms within 6 to 8 hours. After removing anchoring devices, a sharp rap should be enough to separate forms from the Unisorb grout base. Bolts can then be checked for tightness and the machine placed in operation.
RESIN AND HARDENER STORAGE - If partial cans are used, be certain to close covers tightly after measuring out: Shelf life is indefinite, if instructions are followed.

MIX RATIO - By weight-13 parts resin to one part hardener. By volume-71/2 parts resin to one part hardener. YIELD

One pound of Unisorb V-100 Grout will fill 16/2 cubic inches, set up.

\section{OTHER APPLICATIONS}

GROUT ANCHOR BOLTS - Drill hole to a depth 10 to 15 times the bolt diameter. Use a hex-head bolt. Make hole diameter about $1 / 2$. larger than bolt diameter. To set anchor bolt quickly, fill hole about one-third of depth with Unisorb $V-100$ Grout..Preheat bolt to about $150^{\circ} \mathrm{F}$. and put in place Bolt will set permanently in less than one hour. If heat is not

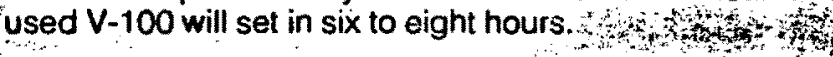
LAY PERFECTLY LEVEL BASES - No transit required, just dam the area to be covered and pour in Unisorb V-100 Grout. It will self-level before setting, then set harder than concrete to a tough, corrosion-resistant base.

MAKE JACKING PADS QUICKLY - Fill in area with clean, sharp crushed stone, scrap metal or other clean tiller to reduce cost. Use at least $1 / 2^{n}$, thickness of Unisorb V-100 Grout:

REINFORCE BEARING SLEEVES AND MACHINE PARTS Instead of enlarging worn bearing support areas and putting in oversize bearings, fill in behind now bearings with Unisorb V-100 Grout.

GROUT FULCRUM PEDESTALS ON TRUCK AND TRACK SCALES - Unisorb V-100 Grout resists shock loading and chemical corrosion - reduces need to regrout, with attendant costs of recalibrating and recertifying.

ADHERE NEW CONCRETE TO OLD - The bond between Unisorb V-100 Grout and concrete is stronger than concrete-to-concrete. Use it as an adhesive film between concretes. (Not recommended for applications to wet concrete).

PATCH FLOORS - Extend Unisorb V-100 Grout with clean fillers, such as pea gravel or crushed stone. Spread clean sand or grit over wet resin surfaces to prevent stipping. Color can be darkened by addition of a small amount of cartion.

\section{PHYSICAL PROPERTIES}

Color

Working Time, $77^{\circ} \mathrm{F}$

Gel Time, $77^{\circ} \mathrm{F}$

Viscosity, $77^{\circ} \mathrm{F}$

Linear Shrinkage

Expansion Coefficient

Compressive Strength

(ASTM D-695)

Compression Modulus

Tensile Strength (ASTM D-638)

Tensile Modulus

Terisile Elongation

Flexural Strength (ASTMD-790)

Flexural Modulus

Gray Green

15 Minutes

30 Minutes (1/2" depth)

$6000 \mathrm{cps}$

0.0013 in./in.

0.000020 in./in./F

9,000 PSI (6-hour cure)

15,250 PSI (3-day cure)

16,800 PSI (7-day cure)

$0.63 \times 10^{6}$ (6-hour cure)

$0.86 \times 10^{6}$ (3-day cure)

$1.10 \times 10^{6}$ (7-day cure)

$4260 \mathrm{PSI}$

$1.13 \times 10^{6}$

$.057 \%$

6800 PSI

$1.26 \times 10^{6}$

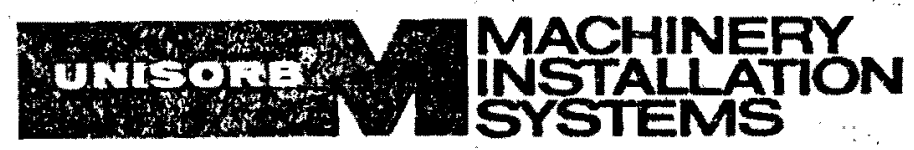

Box 1000, Jackson, Michigan 49204. (517) 764-6060 Telex TWX B10-253-1912 MISUNISORB JKN 


\section{FVE BTAR GROUT}

\section{Non-metallic/Nonshrink}

Five Star Grout is the leading precision, non-metallic, nonshrink grout with a successful performance record unmatched by any competitor. Five Star Grout consistently obtains the highest E.B.A. $(95 \%)$ in the industry. Five Star Grout is unique in that it meets all requirements of CRD-C 621 and shows no shrinkage when tested in accordance with ASTM C-827. It contains no gypsum, aluminum or metallic particles.

\section{Ease of Placement}

Five Star Grout is the most versatile, fool-proof grout available, enabling the contractor to place the material in the easiest, most economical way possible. Five Star Grout exhibits long working time without rapid loss of slump. By varying the amount of water, Five Star Grout can be made into a dry pack, plastic, trowelable, pumpable, or flowable consistency. Five Star Grout may be placed by a variety of methods, including pumps

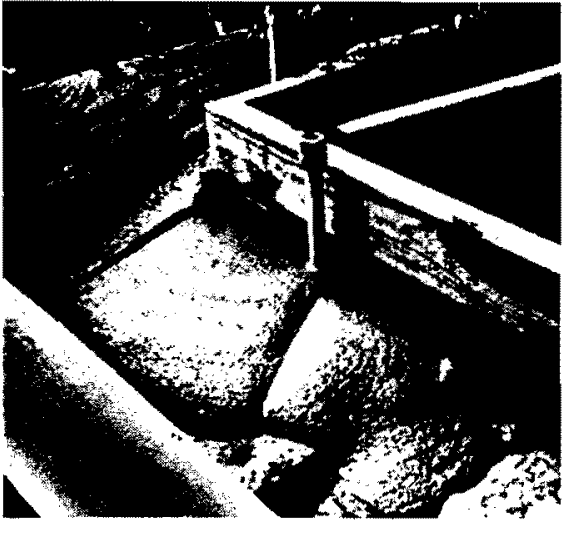

or vibrators, without compromising inplace properties.

\section{Highest Yield/Easy Estimating}

Five Star Grout comes in heavy-duty, polyethylene-lined bags producing one cubic foot for ease in estimating and handling. It often takes two or more bags of a competititor's material to obtain the equivalent yield of one bag of Five Star Grout. Five Star Grout is readily available locally, just call toll free, (800) 243-2206 for the name of our local dealer.
Meets or Exceeds All Requirements Five Star Grout meets or exceeds all nationally-accepted, published standards for high-performance grout, including ASTM C-827 and CRD-C 621. Independent laboratory tests are available.

Typical Compressive Sirengths ASTM C-109

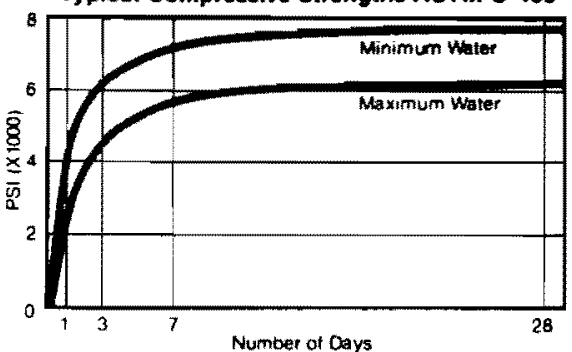

Applications

Five Star Grout has the longest, most extensive history of successful applications of any non-metallic, nonshrink grout on the market. Typical applications include: large, heavy operating equipment, structural columns, anchors, precast and prestressed panels, and patching. For a list of applications similar to yours, call our toll-free number, (800) 243-2206.

\section{FIVE

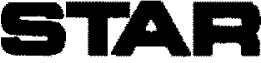 EPOXY GROUT}

Nonshrink/Highest E.B.A.

Five Star Epoxy Grout is the only epoxy grout that shows no shrinkage from time of placement, tested according to ASTM C-827. This unique characteristic ensures full contact ( $95 \%$ E.B.A.) with baseplates and other bearing surfaces, as demonstrated by its proven history of successful use. Most epoxy grouts which exhibit shrinkage in the plastic state develop voids which reduce their capacity to carry load, resist impact, and provide protection against chemical attack.

\section{High Creep Resistance}

Five Star Epoxy Grout is a $100 \%$ solids, three-component system specifically designed to have excellent resistance to creep versus other epoxy grouts. High creep resistance and dimensional stability are critical features of any epoxy grout that must maintain equipment to a precise alignment over time.

\section{Workability/Less Noxious}

Five Star Epoxy Grout has been designed to provide exceptional pourability and flow characteristics while minimizing the loss of bearing area normally encountered with pourable grouts. Five Star Epoxy Grout is less noxious than grouts containing highly volatile diluents or solvents, making installation areas less hazardous for workmen.

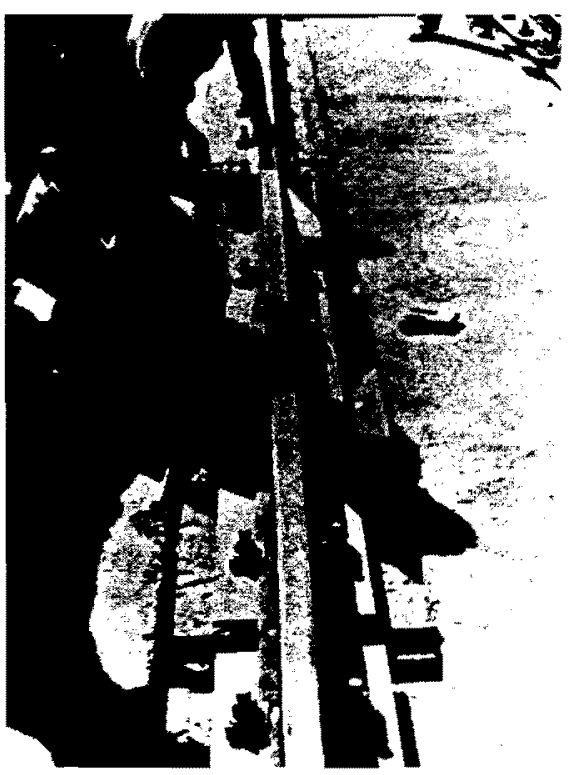

Typical Compressive Strengths ASTM C-109

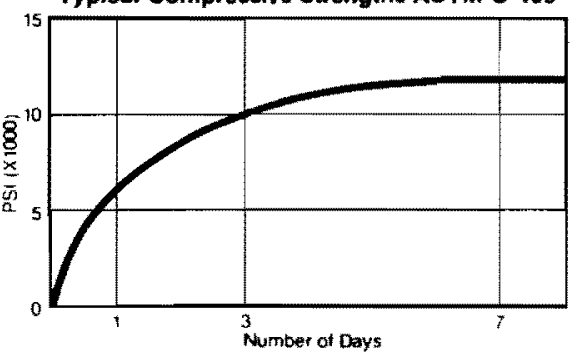

High Chemical/Impact and Vibration Resistance

Five Star Epoxy Grout combines toughness and resiliency to withstand impact and dynamic loads which can crack cementitious grouts. It resists oils, gasoline, alkalies, mild acids, and most aliphatic hydrocarbons. For a more detailed listing of chemical resistance, call toll free, (800) 243-2206.

Tenacious Bond

Five Star Epoxy Grout develops a tenacious bond to almost all clean, dry, surrounding substrates, ensuring high performance. Its bond to concrete is stronger than the concrete.

Other Key Properties

Tensile Strength (ASTM C-307)

Flexural Strength (ASTM C-580)

Flexural Modulus (ASTM C-580)

Coefficient of $\quad 27 \times 10^{-6} \mathrm{in} / \mathrm{in} /{ }^{\circ} \mathrm{F}$ Expansion (ASTM C-531)

\section{Applications}

Five Star Epoxy Grout has an extensive history of successful applications. Typical applications include: high impact vibrating machinery, structural columns, crane raits, chemical-holding tanks, and anchors. 
FIVE BTAR

INSTANT

GROUT

Non-metallic/Nonshrink

Five Star Instant Grout is a rapid strength gain, nonshrink grout for four-hour machinery start-up, cold-weather, and anchor bolt grouting. It never goes below its initial placement volume, as measured by ASTM C-827 and CRD-C 621. These nonshrink properties ensure the highest E.B.A. in the industry. It contains no calcium chloride or other salts, aluminum, or other harmful metals.

\section{Ease of Placement}

Five Star Instant Grout is a versatile, foolproof, fast-set grout. It may be dry packed, troweled, pumped, vibrated, plunged, or flowed into place. For additional working time, Summerset ${ }^{\text {tw }}$ may be added. Call toll free (800) 243-2206, for more information.
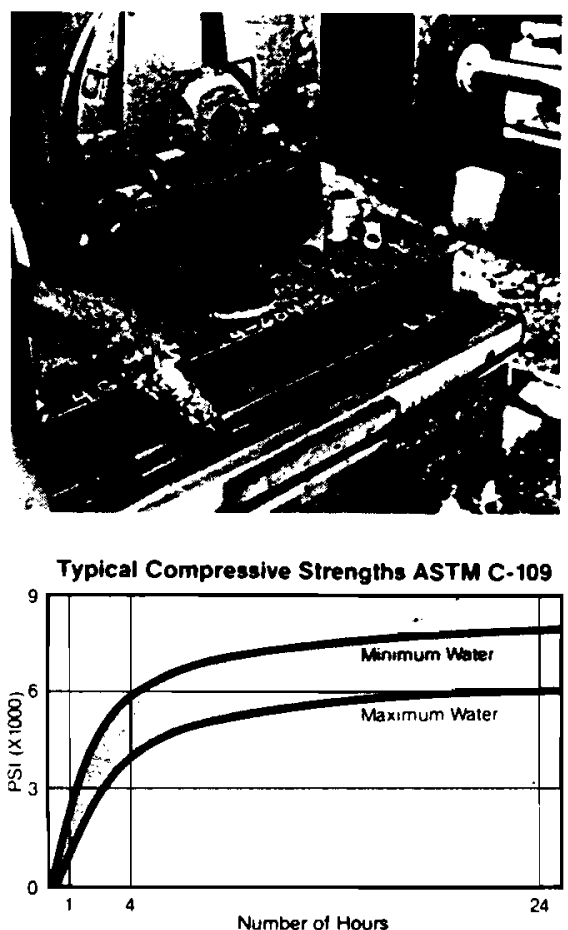

Chemical/Heal Resistance

Five Star Instant Grout is more resistant to oil, gas, sulfates, saltwater, and most chemicals and withstands considerably higher temperatures than Portland cementbased grouts

\section{Cold-Weather Grout}

Five Star Instant Grout is superior to Portland cement-based grouts for coldweather grouting. Its rapid strength gain even at temperatures down to $32^{\circ} \mathrm{F}$ eliminates the long curing time needed by Portland cement grouts.

\section{Convenient Packaging}

Five Star Instant Grout is packaged in resealable, weatherproof, plastic pails which produce roughly $1 / 2$ cubic foot of hardened grout

\section{Applications}

Five Star Instant Grout has an extensive history of successful application. Typical applications include: heavy operating machinery for four-hour start-up. structural columns, repair of concrete structures, and anchor bolts.

\section{SPECIFICATIONS}

\section{Nonshrink Cement-Based Grout}

1. Grout shall consist of premixed, pre-packaged materials supplied by the manufacturer, requiring only the addition of potable water.

\section{Performance Criteria}

A. Nonshrink - No shrinkage when tested in accordance with ASTM C-827 and CRD-C 621.

B. Effective Bearing A.rea - A minimum E.B.A. of $95 \%$.

C. Compressive Strength - A minimum 28-day compressive strength of 5,000 psi when tested in accordance with ASTM C-109.

D. Composition - No metallic particles (catalyzed or non-catalyzed), aluminum powder, or expansive cement.

E. History - A minimum t0-year history of successful use

F. Technical Service shall be supplied upon request.

III. Approved Material

Five Star Grout, as manufactured by U.S. Grout Corporation, Fairfield, Connecticut is considered to comply with this specification.
Nonshrink Epoxy-Based Grout

1. Nonshrink Epoxy-Based Grout shall be a pourable, $100 \%$ solids epoxy system consisting of three premeasured, prepackaged components.

II. Pertormance Criteria

A. Nonshrink - No shrinkage when tested in accordance with ASTM C-827.

B. Effective Bearing Area - A minimum E.B.A. of $95 \%$.

C. Compressive Strength - A minimum compressive strength of 10,000 psi in 7 days when tested according to ASTM C-579, Method B.

D. Thermal Coefficient of Expansion - A maximum $30 \times$ $10^{-6}$ in $/$ in $/{ }^{\circ} \mathrm{F}$ thermal coefficient when tested according to ASTM C-531.

E. History - A minimum 5-year history of successful use.

F. Technical service shall be supplied upon request.

III. Approved Material

Five Star Epoxy Grout, as manufactured by U.S. Grout Corporation, Fairfield, Connecticut is considered to comply with this specification.

\section{U.S. GROUT CORPORATION}

\section{Stillson Road - Fairfield, Connecticut 06430}

Telephone: (203) 336-7900 - Telex: 643857 • Cable: FIVE STAR

Telecopier: (203) 336-7939

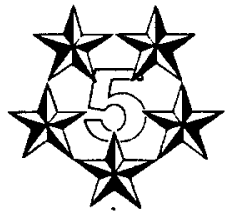

FVE STAR 

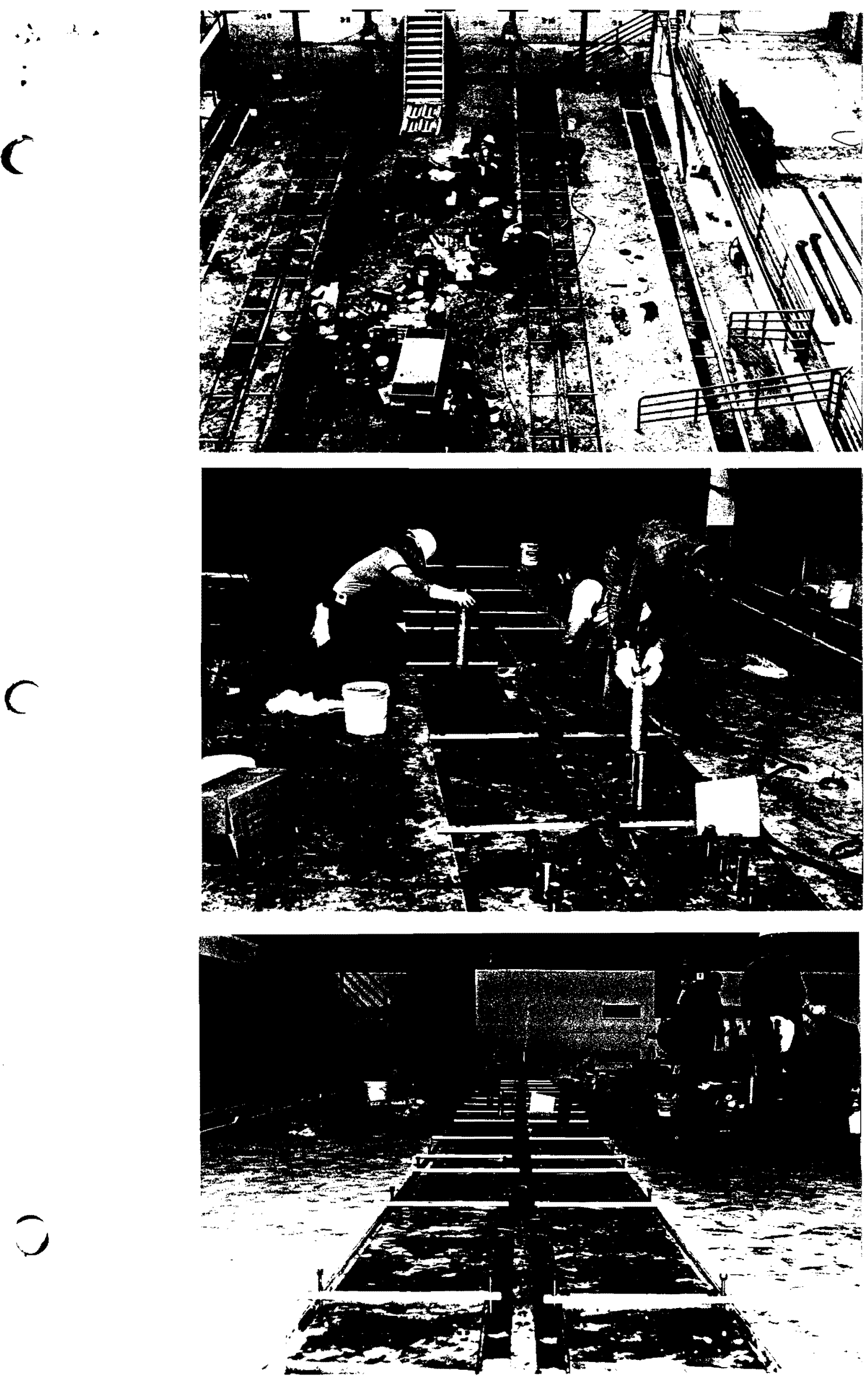

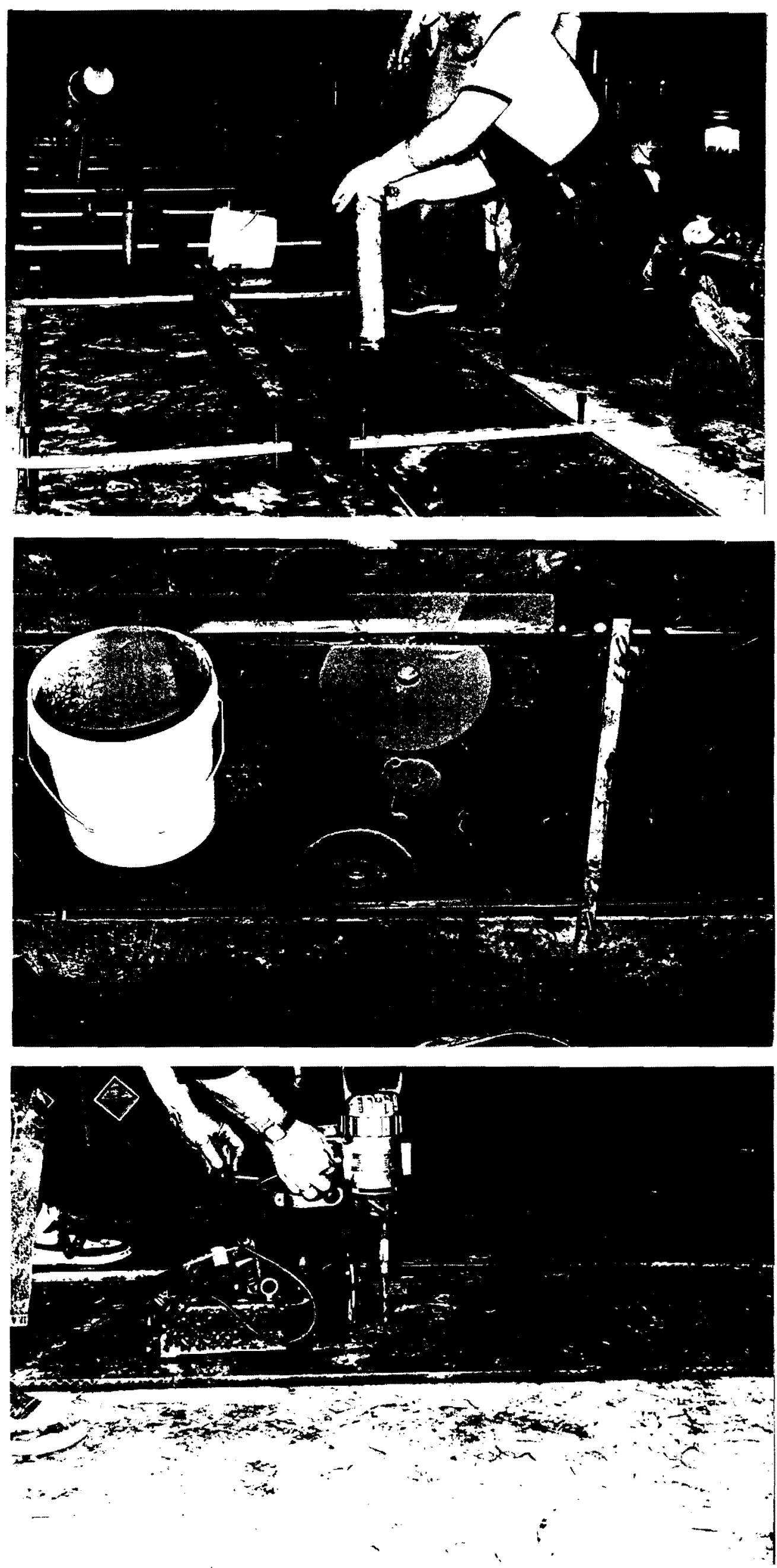